\title{
PENGARUH CORPORATE GOVERNANCE TERHADAP FIRM VALUE MELALUI MEDIASI CAPITAL STRUCTURE DAN FINANCIAL PERFORMANCE
}

\author{
Reza Septianto, Sumiati, Ainur Rofiq \\ Fakultas Ekonomi dan Bisnis Universtitas Brawijaya Malang \\ email:rezasept@ymail.com
}

\begin{abstract}
This study analyzes the Capital Structure mediating role in the influence of Corporate Governance on Firm Value and analyze the performance of financial mediation role in the influence of Corporate Governance on firm value.Researching services sub-sector property and real estate company listed on the Indonesia Stock Exchange. This study used a sample of 15 services sub-sector property companies and real astate listed on the Indonesia Stock Exchange has published its financial reports and audited by independent accountants and companies that have implemented Corporate Governance. The analysis tool in this research using path analysis. The results of this study indicate that: Capital Structure did not prove to mediate the influence of Corporate Governance on Firm Value and Financial Performance shown to mediate the influence of Corporate Governance on firm value. Suggestions can be submitted is recommended to enhance the improvement of management on the use of Corporate Governance system, due to improvements in the quality of Corporate Governance implementation will have an impact on the company's credibility
\end{abstract}

Keywords: Corporate Governance, Capital Structure, Financial Performance, Firm Value

\begin{abstract}
Abstrak: Penelitian ini bertujuan menganalisis peran mediasi Capital Structure dalam pengaruh Corporate Governance terhadap Firm Value serta menganalisis peran mediasi Financial Performance dalam pengaruh Corporate Governance terhadap firm value. Penulis meneliti perusahaan jasa sub sektor property dan real estate yang terdaftar di Bursa Efek Indonesia. Penelitian ini menggunakan sampel sebanyak 15 perusahaan jasa sub sektor property dan real astate yang terdaftar di Bursa Efek Indonesia yang telah mempublikasikan laporan keuangan dan di audit oleh akuntan independent serta perusahaan yang telah menerapkan Corporate Governance. Alat analisis dalam penelitian ini menggunakan analisis jalur (path analysis). Hasil dari penelitian ini menunjukkan bahwa variabel Capital Structure tidak terbukti memediasi pengaruh Corporate Governance terhadap Firm Value dan variabel Financial Performance terbukti memediasi pengaruh Corporate Governance terhadap firm value. Saran yang dapat disampaikan adalah manajemen disarankan untuk meningkatkan perbaikan pada sistem penggunaan Corporate Governance, karena perbaikan pada kualitas penerapan Corporate Governance akan berdampak pada kredibilitas perusahaan
\end{abstract}

Kata Kunci: Corporate Governance, Capital Structure, Financial Performance, Firm Value

Firm Value merupakan hal yang sangat penting bagi perusahaan go public karena Firm Value menggambarkan kesejahteraan shareholders (Wardani dan Hermuningsih, 2011). Manajemen perusahaan diharapkan dapat meningkatkan Firm Value dari waktu ke waktu, karena peningkatan nilai perusahaan mencerminkan peningkatan kesejahteraan pemegang saham. Peningkatan Firm Value dapat digunakan sebagai parameter keberhasilan manajemen didalam mengelola perusahaan. Firm Value yang tinggi tentu akan direspon secara positif di pasar modal. Melalui peningkatan Firm Value, maka shareholders akan memperoleh manfaat yang berasal dari capital gain. Nilai perusahaan mencerminkan penilaian kolektif investor mengenai seberapa baik keadaan atau kondisi suatu perusahaan, baik kinerja pada saat ini, maupun prospeknya di masa yang akan datang (Brealy et al. 2006:46).

Penelitian terdahulu yang dilakukan oleh Cho and Pucik (2005), Amidu (2007), Byun et al., (2007), Kim (2007), Garay dan Gonzalez (2008), dan Florackis et al. (2009) dan Setiabudi dan Agustia (2012) menemukan bukti bahwa Firm Value dipengaruhi oleh beberapa faktor seperti Financial 
Performance, kebijakan Capital Structure, dan Corporate Governance. Faktor pertama yang menjadi determinan Firm Value adalah Financial Performance. Financial Performance merupakan hal terpenting dalam sebuah organisasi bisnis. Financial Performance merupakan cerminan bahwa manajemen mampu menciptakan laba bagi perusahaan. Bagi sebuah organisasi bisnis, laba merupakan aspek yang sangat penting sebuah perusahaan. Tinggi rendahnya laba akan menentukan bagaimana kelangsungan hidup perusahaan dimasa mendatang. Perusahaan yang memiliki Financial Performance yang tinggi tentu akan menjadi perhatian utama bagi investor didalam berinvestasi. Perusahaan dengan Financial Performance baik, juga berarti bahwa perusahaan memiliki sumber pendanaan internal yang baik pula dimasa mendatang.

Penelitian terdahulu yang menguji pengaruh antara Financial Performance terhadap Firm Value dilakukan oleh Cho and Pucik (2005), Byun et al., (2007), dan Setiabudi dan Agustia (2012) yang menemukan bukti bahwa Financial Performance memiliki pengaruh yang positif dan signifikan teerhadap Firm Value. Financial Performance yang bagus akan diikuti oleh peningkatan Firm Value. Financial Performance yang bagus mencerminkan bahwa perusahaan mampu meningkatkan laba, adanya peningkatan penjualan, efisiensi biaya operasional, dan perluasan pasar. Financial Performance yang bagus akan mendorong peningkatan aset yang dimiliki oleh perusahaan dan ketersediaan sumber pendanaan internal perusahaan. Oleh karena itu, perusahaan yang memiliki Financial Performance yang bagus dipandang memiliki prospek yang bagus dimasa mendatang.

Faktor kedua yang menjadi determinan Firm Value adalah kebijakan struktur modal. Penelitian tentang pengaruh kebijakan struktur modal terhadap Firm Value sudah menjadi perdebatan menarik, sejak Miller dan Modigliani (MM)1958 menyatakan bahwa Capital Structure tidak berpengaruh terhadap peningkatan Firm Value. Sejumlah peneliti seperti Amidu (2007), Kim (2007), Garay dan Gonzalez (2008), dan Florackis et al. (2009) mendukung teori ini. Mereka menemukan bukti bahwa Capital Structure tidak berpengaruh terhadap Firm Value. Namun, pendapat MM tersebut tidak sepenuhnya benar karena MM menggunakan beberapa macam asumsi yang dipandang tidak realistis seperti tidak adanya pajak, biaya kebangkrutan, biaya agensi, dan tidak adanya asimetri informasi. Kemudian pada tahun 1963, MM melanjutkan penelitiannya dengan menggunakan asumsi keberadaan pajak. Penelitian MM yang selanjutnya menyatakan bahwa Capital Structure berpengaruh positif terhadap Firm Value.

Manajemen perusahaan yang disebut dengan istilah "agen" seringkali berbenturan dengan kepentingan pemegang saham yang disebut dengan "prinsipal". Masing-masing pihak baik agen maupun prinsipal memiliki kepentingan masing-masing. Manajer lebih banyak menggunakan laba perusahaan untuk kepentingan pribadinya dan melakukan reinvestasi pada proyek yang mereka sukai. Sedangkan investor menghendaki manajer untuk meningkatkan Firm Value dan membagikan laba dalam bentuk dividen. Kondisi ini yang menimbulkan biaya agensi. Penggunaan hutang untuk mendanai investasi membuat tingkat kontrol terhadap manajer semakin meningkat, sehingga manajer akan berhati-hati didalam mengelola dana tersebut. Penggunaan hutang yang tinggi dianggap sebagai sebuah sinyal positif mengenai potensi keuntungan perusahaan di masa mendatang, sehingga jumlah hutang yang tinggi maka akan mampu meningkatkan Firm Value.

Penelitian mengenai Corporate Governance di Indonesia merupakan suatu kajian yang menarik. Penerapan Corporate Governance pada sebuah perusahaan diharapkan mampu meningkatkan Firm Value. Perusahaan yang menerapkan prinsip Corporate Governance lebih menarik bagi investor dibandingkan perusahaan yang tidak menerapkan prinsip Corporate Governance . Kondisi ini dapat terjadi karena perusahaan yang menerapkan prinsip Corporate Governance bersifat lebih transparan, kredibel, independen, dan akuntabel. Corporate Governance memiliki pengaruh yang kompleks bagi sebuah perusahaan, tidak hanya pada Firm Value, namun juga pada kebijakan Capital Structure dan Financial Performance pada suatu perusahaan.

Tujuan penelitian kali ini adalah untuk menguji pengaruh Corporate Governance terhadap Firm Value yang dimediasi oleh Capital Structure dan Financial Performance. Berdasarkan teori yang ada dan beberapa penelitian terdahulu indikator-indikator dalam 
penelitian ini adalah untuk variabel Corporate Governance diproksi menggunakan indikator komite audit independen, variabel Capital Structure di proksi menggunakan indikator debt equity ratio, variabel Financial Performance diproksi menggunakan indikator ROA dan variabel fim value diproksi menggunakan indikator tobin's $q$. Dengan penggunaan proksiproksi tersebut penelitian ini dapat mengisi celah penelitian terdahulu terutama pada penerapan Corporate Governance pada Perusahaan Sub Sektor Property dan Real estate.

Penelitian yang dilakukan oleh Cremers and Nair, (2005), menemukan bukti bahwa Corporate Governance memiliki pengaruh yang positif dan signifikan terhadap Firm Value. Penerapan konsep Corporate Governance mampu menurunkan agency conflict sehingga perusahaan bergerak sepenuhnya untuk kepentingan para stakeholders. Penelitian ini akan menggunakan indikator komite audit independen untuk mengukur variabel Corporate Governance. Komite audit dianggap sebagai penghubung antara pemegang saham dan dewan komisaris dengan pihak manajemen guna mengatasi masalah pengendalian ataupun kemungkinan timbulnya agency conflict (Amri dan Untara, 2011).

\section{Pengembangan Hipotesis}

Garay dan Gonzalez (2008) mengatakan bahwa Corporate Governance berpengaruh signifikan terhadap nilai perusahaan, dimana indikator Corporate Governance menggunakan Corporate Governance indeks dan Firm Value menggunakan proksi Tobin's Q dan PBV. Hasil penelitian ini dipengaruhi oleh Corporate Governance secara formalitas dan tegas terhadap perusahaan di Venezuela. Para pemegang saham mempunyai kerangka berpikir penerapan Corporate Governance pada perusahaan merupakan hal yang penting untuk menggeser pola pikir atau paradigma lama yang masih bergantung pada variabel lain untuk menilai perusahaan. Sehingga nilai perusahaan akan meningkat dengan peningkatan persepsi pada perusahaan yang menerapkan Corporate Governance. Oleh karena itu hipotesis yang diajukan adalah :

\section{$\mathrm{H}_{1}$ : Corporate Governance berpengaruh signifikan terhadap Firm Value pada}

perusahaan sub sektor property dan real estate

Dewan direksi bertugas untuk mengurus perusahaan, sementara dewan komisaris bertugas untuk melakukan pengawasan. Selain itu, komisaris independen bertugas sebagai kekuatan penyeimbang dalam pengambilan keputusan oleh dewan komisaris. Amidu (2007) menyimpulkan bahwa ownwership structure, managerial compensation, dan board structure memiliki pengaruh yang kuat terhadap komposisi struktur modal perusahaan. Oleh karena itu hipotesis yang diajukan adalah :

$\mathrm{H}_{2}$ : Corporate Governance berpengaruh signifikan terhadap capital structure pada perusahaan sub sektor property dan real estate

Klapper dan Love (2002) menemukan bahwa Corporate Governance berpengaruh signifikan terhadap kinerja keuangan perusahaan. Dimana perusahaan yang menerapkan Corporate Governance secara konsisten akan memperoleh manfaat yang lebih besar pada negara yang lingkungan hukumnya buruk. Klapper dan Love (2002) menggunakan kinerja perusahaan yang di proksi menggunakan ROA dan menggunakan tingkat keberhasilan hukum yang di proksi dengan efisiensi yudisial, hak pemegang saham dan legalitas sebagai variabel dependen, serta variabel Corporate Governance sebagai variabel independen. Oleh karena itu hipotesis yang diajukan adalah :

\section{$\mathrm{H}_{3}$ : Corporate Governance berpengaruh signifikan terhadap Financial Performance pada perusahaan sub sektor property dan real estate}

Merujuk pendapat Brigham dan Ehrhardt (2005:547) dapat disimpulkan bahwa Capital Structure adalah merupakan kombinasi antara komposisi hutang dengan modal sendiri untuk memenuhi kebutuhan pendanaan perusahaan. Capital Structure merupakan salah satu strategi yang dapat digunakan untuk meningkatkan Firm Value. Oleh karena itu, strategi dan kebijakan Capital Structure harus diformulasikan dengan tepat agar perusahaan mampu menciptakan komposisi pendanaan yang ideal, sehingga mampu meningkatkan Firm Value. Oleh karena itu hipotesis yang diajukan adalah : 
$\mathrm{H}_{4}$ :Capital Structure memediasi pengaruh Corporate Governance terhadap Firm Value pada perusahaan sub sektor property dan real estate

Cho dan Pucik (2005) menyimpulkan bahwa pertumbuhan dan profitabilitas memiliki pengaruh yang signifikan terhadap Firm Value. Semakin besar hasil profitabilitas maka kinerja keuangan perusahaan semakin baik, rasio yang meningkat menunjukkan bahwa kinerja manajemen meningkat dalam mengelola sumber dana pembiayaan operasional secara efektif untuk menghasilkan laba bersih. Hal tersebut akan berdampak positif pada peluang pertumbuhan perusahaan dan keyakinan investor dalam penempatan investasinya. Oleh karena itu hipotesis yang diajukan adalah :
$\mathrm{H}_{5} \quad$ :Financial Performance memediasi pengaruh Corporate Governance terhadap Firm Value pada perusahaan sub sektor property dan real estate.

Corporate Governance adalah serangkaian mekanisme yang mengarahkan dan mengendalikan perusahaan agar operasional perusahaan berjalan sesuai dengan pemangku kepentingan (stakeholder) karena terdapat permisahaan antara kepemilikan dengan pihak manajemen sebagai pihak yang menjalankan perusahaan. Diterapkannya prinsip-prinsip dalam Corporate Governance dapat mengurangi masalah keagenan yang diakibatkan oleh perbedaaan kepentiangan antara pemilik dan pengelola (pihak manajemen). Berikut kerangka konseptual penelitian:

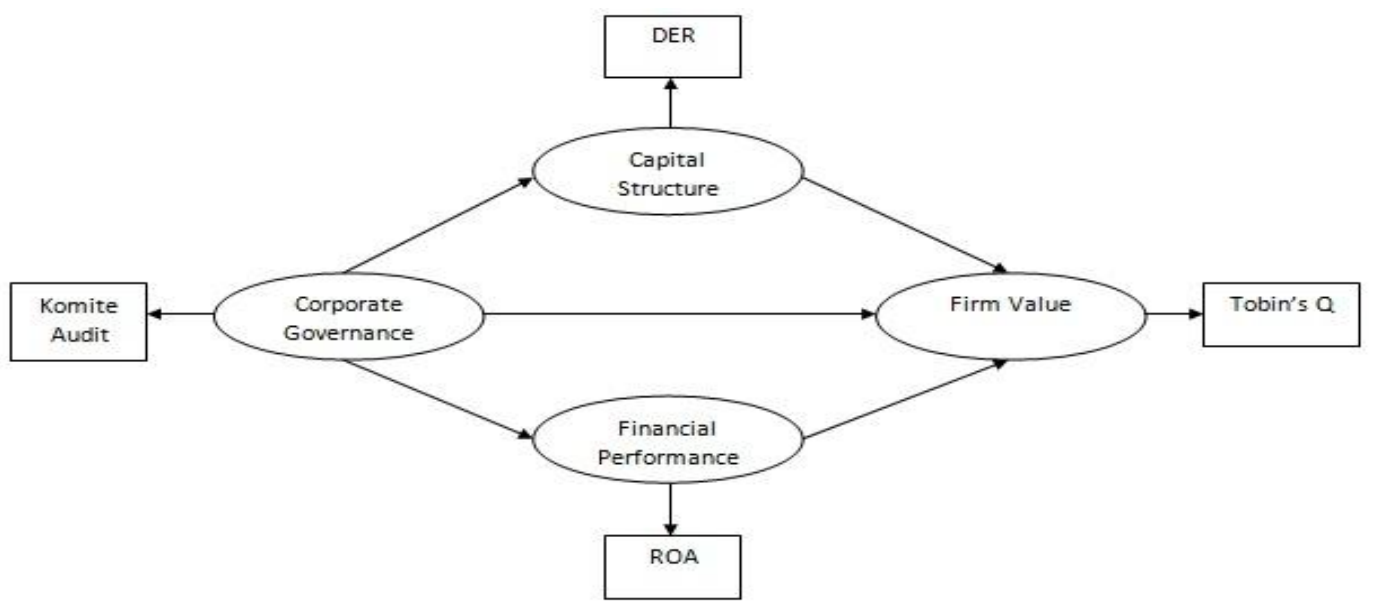

Gambar 1. Kerangka Konseptual

\section{Metode Penelitian}

Penelitian ini menggunakan pendekatan kuantitatif. Ditinjau dari jenis penelitian, maka penelitian ini tergolong penelitian explanatori atau penjelasan. Penelitian ini bertujuan untuk menguji pengaruh Corporate Governance (variable bebas) yang diwakili oleh Komite Audit Independen terhadap Firm Value (variabel terikat) yang diwakili oleh Tobins'Q melalui variable mediasi yaitu Capital Structure yang diwakili oleh Debt Equity Ratio dan Financial Performance yang diwakili oleh Return on Asset.

\section{Populasi dan Sampel}

Populasi yang digunakan dalam penelitian ini adalah perusahaan jasa sub sektor property dan real estate yang terdaftar di BEI periode tahun 2011-2014. Pemilihan sampel menggunakan metode purposing sampling. Sampel diperoleh sebanyak 15 perusahaan sub sektor property dan real estate, sehingga didapatkan sampel (n) selama periode tiga tahun yaitu 45 sampel (15 perusahaan $\times 3$ tahun).

\section{Definisi Operasional}

\section{Corporate Governance}

Corporate Governance merupakan suatu sistem yang dipakai board untuk mengarahkan 
dan mengendalikan serta mengawasi pengelolaah sumber daya dengan prinsipprinsipnya yaitu transparan, akuntabel, responsible, independent dan fairness dalam mencapai tujuan organisasi. Penerapan Corporate Governance suatu perusahaan dapat diukur menggunakan indikator yaitu Komite audit independen. Komite audit bertanggung jawab untuk mengawasi laporan keuangan, mengawasi audit eksternal, dan mengamati sistem pengendalian internal (termasuk audit internal). Komite audit dapat mengurangi sifat opportunistik manajemen yang melakukan manajemen laba dengan cara mengawasi laporan keuangan dan melakukan pengawasan pada audit eksternal (Zarkasyi, 2008). Komite audit independen dinyatakan dalam rumus (Coleman, 2007:10) :

Komite Audit : Jumlah audit independen

$$
\text { Jumlah audit komite }
$$

\section{Capital Strucutre}

Capital Structure merupakan rasio yang digunakan untuk mengukur tingkat solvabilitas perusahaan. Capital Structure adalah perbandingan atau imbangan pendanaan jangka panjang terhadap modal sendiri. Dalam penelitian ini Capital Structure diukur menggunakan Debt Equity Ratio, penggunaan ratio DER dalam penelitian ini dengan alasan bahwa tingkat struktur modal yang optimal ditentukan oleh trade off antara manfaat dan biaya penggunaan utang, dan dan DER mampu menggambarkan besarnya sumber modal yag berasal dari utang (Sutrisno, 2003:249). Indikator Capital Structure pada penelitian ini menggunakan indikator DER yaitu perbandingan antara hutang jangka panjang dengan modal pemegang saham (Sundjaja dan Barlian 2003:141):

\section{DER :Total hutang jangka panjang} Ekuitas pemegang saham

\section{Financial Performance}

Financial Performance adalah hasil upaya manajemen dalam memanfaatkan peluang untuk memperoleh hasil terbaik dengan pilihan risiko terendah (Hunger dan Wheelen, 2004). Ukuran Financial Performance yang digunakan dalam penelitian ini adalah menggunakan indikator ROA. Return On Asset merupakan perbandingan antara laba setelah pajak dengan total aktiva. Digunakannya ROA sebagai alat ukur Financial Performance karena ROA menggambarkan keuntungan yang diperoleh dengan total aktiva (Sutrisno, 2003:254). Rumus ROA adalah sebagai berikut ( Ruan et al. 2011) :

\section{ROA : Net Profit After Taxes Total Assets}

\section{Firm Value}

Firm Value adalah persepsi investor terhadap tingkat keberhasilan perusahaan. Pada perusahaan publik respon investor ini dapat dicerminkan pada seputar aktivitas perdagangan saham, karena saham mencerminkan informasi tentang laba potensial dari perusahaan. Tobin's $q$ adalah indikator untuk mengukur kinerja perusahaan, khususnya tentang nilai perusahaan yang menunjukkan suatu performa manajemen dalam mengelola aktiva perusahaan. Rumus yang digunakan untuk mengukur Tobin's $q$ adalah nilai pasar saham ditambah dengan hutang pasar saham di bagi dengan total aset produksi (Klapper dan Love dalam Hosiana, 2012:35) :

Tobin's q: $\underline{M E+D e b t}$

\section{Total Aset}

\section{Sumber Data}

Data sekunder diperoleh dari Bursa Efek Indonesia melalui website resmi BEI di situs www.idx.co.id. Periode penelitian yang digunakan dalam penelitin ini adalah 3 tahun, periode penelitian untuk variabel Corporate Governance, Capital Structure dan Financial Performance menggunakan periode 2011, 2012 dan 2013. Sedangkan periode penelitian untuk variabel Firm Value adalah menggunakan periode 2012, 2013 dan 2014.

\section{Metode Analisis Data}

Metode analisis data dalam penelitian ini menggunakan analisis jalur (path analysis). Pengujian hipotesis pengaruh langsung dilakukan dengan melihat nilai probabilitas variabel. Hipotesis diterima bila nilai probabilitas $<0.05$. Pengujian pengaruh tidak langsung antara variabel independen terhadap variabel dependen melalui variabel intervening diperoleh dari hasil kali pengaruh langsung 
antara variabel independen terhadap variabel intervening dan pengaruh langsung antara variabel intervening terhadap variabel dependen. Hipotesis pengaruh tidak langsung diterima jika nilai koefisien jalur pada koefisien tidak langsung harus signifikan semua. (Riduwan dan Kuncoro, 2011:45).

\section{HASIL DAN PEMBAHASAN Asumsi Multikolinieritas}

Untuk mendeteksi multikolinieritas adalah dengan menggunakan nilai Variance Inflation Factor (VIF). Apabila nilai VIF > 10 maka menunjukkan adanya multikolinieritas. Sebaliknya apabila VIF < 10 maka tidak terjadi multikolinieritas. Masing-masing variabel independen menunjukkan nilai VIF yang tidak lebih dari nilai 10 dan Tolerance yang bernilai lebih dari 0,1 , sehingga disimpulkan bahwa tidak terjadi gejala multikolinieritas dalam data.

\section{Asumsi Heteroskedastisitas}

Untuk menguji Heterosdastitas adalah dengan menggunakan Uji Glejser. Uji Glejser dilakukan dengan cara meregresikan antara variabel independen dengan nilai absolute residualnya. Jika nilai signifikansi antara variabel independen dengan absolute residualnya lebih dari 0,05 maka tidak terjadi masalah heteroskedastisitas. Dalam penelitian ini pada persamaan 1,2 , maupun 3 diketahui bahwa nilai signifikansi variabel independen terhadap variabel dependen, yaitu nilai absolute residual bernilai lebih dari 0,05 . Sehingga dapat disimpulkan bahwa persamaan-persamaan 1, 2, dan 3 terbebas dari masalah heteroskedastistas.

\section{Tabel 1. Hasil Uji Glesjer}

\begin{tabular}{|c|c|c|c|c|}
\hline Persamaan & Variabel Dependen & T & Signifikansi & Hasil \\
\hline Persamaan 1 & Capital Structure & 0,163 & 0,871 & $\begin{array}{c}\text { Tidak terdapat } \\
\text { heteroskedastisitas }\end{array}$ \\
\hline Persamaan 2 & Financial Performance & 0,812 & 0,421 & $\begin{array}{c}\text { Tidak terdapat } \\
\text { heteroskedastisitas }\end{array}$ \\
\hline Persamaan 3 & Corporate Governance & 1,019 & 0,314 & $\begin{array}{c}\text { Tidak terdapat } \\
\text { heteroskedastisitas }\end{array}$ \\
\cline { 2 - 5 } & Capital Structure & $-0,234$ & 0,816 & $\begin{array}{c}\text { Tidak terdapat } \\
\text { heteroskedastisitas }\end{array}$ \\
\cline { 2 - 5 } & Financial Performance & $-0,612$ & 0,544 & $\begin{array}{c}\text { Tidak terdapat } \\
\text { heteroskedastisitas }\end{array}$ \\
\hline
\end{tabular}

Sumber : Hasil Pengolahan (2016)

\section{Asumsi Normalitas}

Hasil uji Kolmogorov-Smirnov baik pada Persamaan 1, 2, maupun 3 menunjukkan nilai signifikansi yang lebih besar daripada
0,050. Sehingga dapat disimpulkan bahwa model regresi pada Persamaan 1, 2, dan 3 layak digunakan dalam penelitian.

Tabel 2. Uji One-Sample Kolmogorov-Smirnov

\begin{tabular}{|c|c|c|c|}
\hline Persamaan & Statistik Uji & Nilai & Keterangan \\
\hline \multirow{2}{*}{ Persamaan 1 } & Kolmogorov-Smirnov Z & 0,716 & \multirow{2}{*}{ Menyebar Normal } \\
\cline { 2 - 3 } & Signifikansi & 0,684 & \\
\hline \multirow{2}{*}{ Persamaan 2 } & Kolmogorov-Smirnov Z & 1,115 & \multirow{2}{*}{ Menyebar Normal } \\
\cline { 2 - 3 } & Signifikansi & 0,812 & \\
\hline \multirow{2}{*}{ Persamaan 3 } & Kolmogorov-Smirnov Z & 0,856 & \multirow{2}{*}{ Menyebar Normal } \\
\cline { 2 - 3 } & Signifikansi & 0,456 & \\
\hline
\end{tabular}

Sumber : Hasil Pengolahan (2016) 


\section{Pengujian Hipotesis}

$\mathrm{H}_{1}$ : Corporate Governance berpengaruh signifikan terhadap Firm Value pada perusahaan sub sektor property dan real estate

Pengujian hipotesis pertama menyatakan bahwa Corporate Governance berpengaruh signifikan terhadap Firm value. Berdasarkan hasil analisis diperoleh nilai koefisien path adalah 0,050 adalah tidak signifikan karena signifikansi sebesar 0,748 karena signifikansi t lebih besar dari $\alpha(0,748>0,05)$ dengan demikian hipotesis pertama ditolak.

\section{$\mathrm{H}_{2}$ : Corporate Governance berpengaruh signifikan terhadap capital structure pada perusahaan sub sektor property dan real estate}

Pengujian hipotesis kedua menyatakan bahwa Corporate Governance berpengaruh signifikan terhadap Capital structure. Berdasarkan hasil analisis diperoleh nilai koefisien path adalah $-0,011$ adalah tidak signifikan karena signifikansi sebesar 0,944 karena signifikansi t lebih besar dari $\alpha(0,944>$ $0,05)$ dengan demikian hipotesis kedua ditolak.

\section{$\mathrm{H}_{3}$ : Corporate Governance berpengaruh signifikan terhadap Financial Performance pada perusahaan sub sektor property dan real estate}

Pengujian hipotesis ketiga menyatakan bahwa Corporate Governance berpengaruh signifikan terhadap Financial Performance. Berdasarkan hasil analisis diperoleh nilai koefisien path adalah 0,296 dan pengaruh adalah signifikan karena signifikansi sebesar 0,048 karena signifikansi t lebih kecil dari $\alpha$ $(0,048<0,05)$ dengan demikian hipotesis ketiga diterima.

Tabel 3. Hasil Pengujian Hipotesis Pengaruh Langsung dan Tidak Langsung

\begin{tabular}{|c|c|c|c|c|c|}
\hline Pengaruh & Variabel Independen & $\begin{array}{c}\text { Variabel } \\
\text { Mediasi }\end{array}$ & Variabel Dependen & Path & Keterangan \\
\hline \multirow{4}{*}{$\begin{array}{c}\text { Tidak } \\
\text { Langsung }\end{array}$} & Corporate Governance & $\begin{array}{c}\text { Capital } \\
\text { Structure }\end{array}$ & Firm Value & - & Tidak Signifikan \\
\cline { 2 - 7 } & Corporate Governance & $\begin{array}{c}\text { Financial } \\
\text { Performance }\end{array}$ & Firm Valu $)$ & $-0,102$ & Signifikan \\
\hline \multirow{5}{*}{ Langsung } & Corporate Governance & - & Capital Structure & $-0,011$ & Tidak Signifikan \\
\cline { 2 - 7 } & Corporate Governance & - & Financial Performance & 0,296 & Signifikan \\
\cline { 2 - 7 } & Corporate Governance & - & Firm Value & 0,050 & Tidak Signifikan \\
\cline { 2 - 7 } & Capital Structure & - & Firm Value & 0,015 & Tidak Signifikan \\
\cline { 2 - 7 } & Financial Performance & - & Firm Value & $-0,337$ & Signifikan \\
\hline
\end{tabular}

Sumber : Hasil Pengolahan (2016)

\section{$\mathrm{H}_{4}$ : Capital Structure memediasi pengaruh Corporate Governance terhadap Firm Value pada perusahaan sub sektor property dan real estate}

Pengaruh tidak langsung antara Corporate Governance terhadap Firm Value melalui capital strucutre diperoleh dari hasil kali pengaruh langsung antara Corporate Governance terhadap Capital Structure dan pengaruh langsung antara Capital Structure terhadap Firm Value sehingga pengaruh tidak langsung sebesar $-0,011 \times 0,015=-0,00017$. Karena pengaruh langsung antara Corporate Governance terhadap Capital Structure adalah tidak signifikan dan pengaruh langsung antara capital strucutre terhadap Firm Value adalah tidak signifikan, maka pengaruh tidak langsung Corporate Governance terhadap Firm Value melalui Capital Structure adalah tidak signifikan.

$\mathrm{H}_{5}$ : Financial Performance memediasi pengaruh Corporate Governance terhadap Firm Value pada perusahaan sub sektor property dan real estate

Pengaruh tidak langsung antara Corporate Governance terhadap Firm Value melalui Financial Performance diperoleh dari hasil kali 
pengaruh langsung antara Corporate Governance terhadap Financial Performance dan pengaruh langsung antara Financial Performance terhadap Firm Value sehingga pengaruh tidak langsung sebesar 0,296 $\times-0,337$ $=-0,0997$. Karena pengaruh langsung antara Corporate Governance terhadap Financial
Performance adalah signifikan dan pengaruh langsung antara Financial Performance terhadap Firm Value adalah signifikan, maka pengaruh tidak langsung Corporate Governance terhadap Firm Value melalui Financial Performance adalah signifikan.

\section{Gambar 2. Hasil analisis jalur (path)}

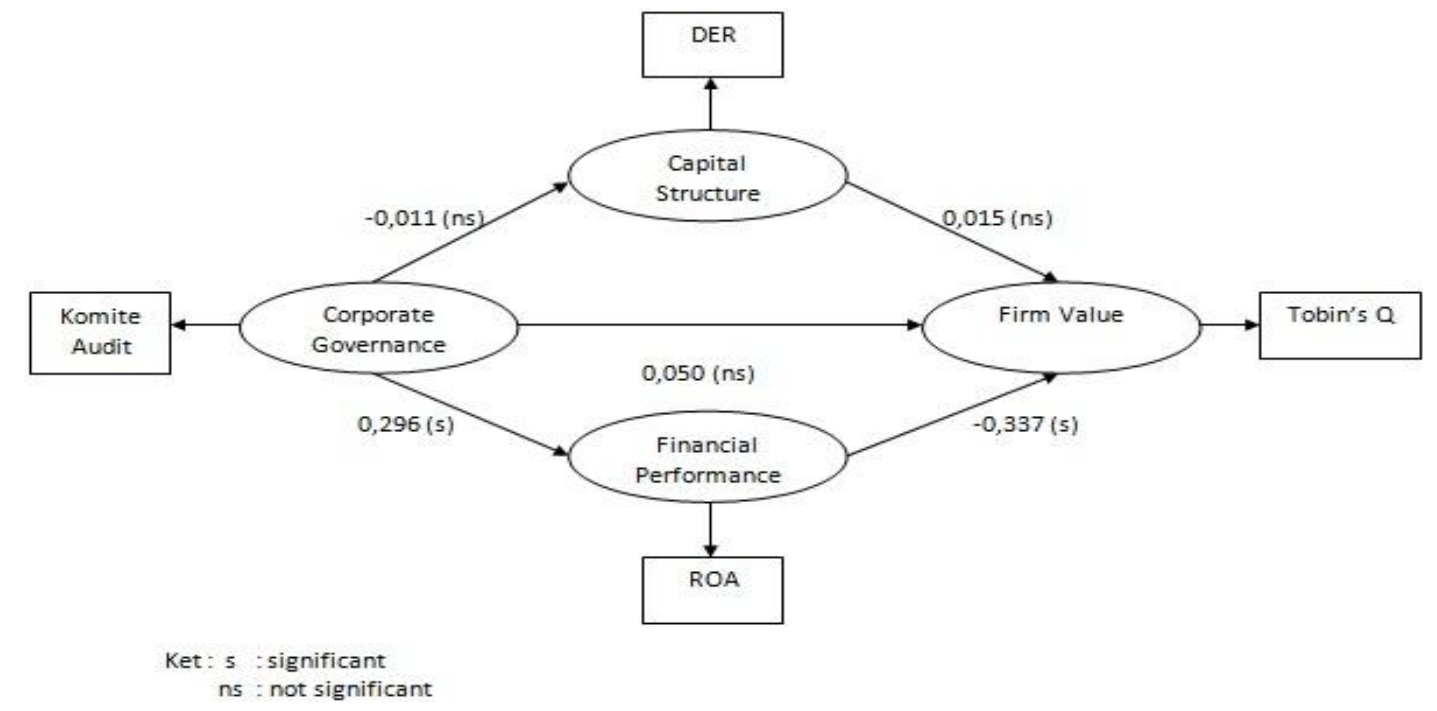

Sumber: : Data Pengolahan (2016)

\section{Pembahasan}

1. Pengaruh Corporate Governance terhadap Firm Value

Hasil penelitian ini disimpulkan bahwa Corporate Governance tidak berpengaruh kepada firm value, dalam penelitian ini variabel Corporate Governance menggunakan indikator komite audit independen tidak berpengaruh terhadap Firm Value hal ini diduga para investor belum tentu memahami kapasitas dari anggota komite audit pada perusahaan hal ini dikarenakan komite audit hanya dijadikan formasi struktural formalitas pada perusahaan publik untuk memenuhi persyaratan Corporate Governance.

Sehingga dalam penelitian ini ditemukan bahwa pengaruh Corporate Governance dengan proksi komite audit tidak berdampak pada potensi pertumbuhan di perusahaan jasa sub sektor property dan real estate. Dengan kata lain pada akhirnya para investor tetap mempertimbangkan faktor lain yang lebih dominan seperti Financial Performance perusahaan dalam mengambil keputusan investasi. Hasil penelitian tersebut bertentangan dengan penelitian dari Garay dan Gonzalez
(2008) yang menemukan menemukan Corporate Governance berpengaruh positf dan signifikan terhadap nilai perusahaan.

2. Pengaruh Corporate Governance terhadap Capital structure

Pengaruh Corporate Governance yang diwakili dengan indikator komite audit independen dalam penelitian ini dapat disimpulkan tidak signifikan terhadap capital strucure. Hal tersebut menunjukkan bahwa komite audit independen belum secara optimal dapat mempengaruhi keputusan penggunaan kewajiban untuk digunakan dalam penambahan modal. Alasan yang mendasari hasil uji penelitian ini adalah dengan adanya komite audit independen di suatu perusahaan yang menerapkan Corporate Governance hanya sebagai formalitas belaka, sementara pemegang saham mayoritas (blockholders) masih memegang peranan penting, sehingga kinerja perusahaan tidak meningkat atau dapat menjadi turun (Boediono, 2005). Penelitian ini sejalan dengan penelitian Hadiprajitno (2012), yang meneliti hubungan good Corporate Governance terhadap capital structure. Dari 
hasil penelitian yang dilakukan, menunjukkan bahwa good Corporate Governance tidak berpengaruh terhadap kebijakan hutang perusahaan manufaktur di Indonesia.

\section{Pengaruh Corporate Governance terhadap Financial Performance}

Pengaruh Corporate Governance dalam penelitian ini berpengaruh signifikan positif terhadap Financial Performance. Hal ini disebabkan oleh ditegakkannya praktik tata kelola yang baik melalui komite audit akan tercitpa prinsip-prinsip dalam Corporate Governance seperti keterbukaan, pengungkapan dan transparansi keuangan. Dengan penerapan prinsip-prinsip tersebut secara otomatis akan membangun keterbukaan atas kebijakan-kebijakan yang dikeluarkan oleh manajemen sehingga kelalaian ataupun kesalahan dapat diminimalisir.

Dan pada akhirnya akan berdampak pada pencapaian laba perusahaan yang maksimal. Selain itu dengan dengan adanya mekanisme Corporate Governance yaitu komite audit independen hal ini menuntut manajemen perusahaan untuk lebih transparan dan akuntabel dalam meningkatkan kinerja keuangan mereka karena dengan prinsip transparansi dan akuntabilitas akan mengurangi risiko yang mungkin dilakukan oleh dewan dengan keputusan yang menguntungkan sendiri. Penelitian ini sejalan penelitian yang dilakukan oleh Klapper dan Love (2002) juga menemukan bahwa Corporate Governance berpengaruh signifikan terhadap kinerja operasi perusahaan.

4. Capital Structure memediasi pengaruh Corporate Governance terhadap firm value Hasil penelitian ini mengindikasikan semakin tinggi atau rendah hutang yang dimiliki sebuah perusahaan tidak mempengaruhi firm value. Karena Firm Value tidak hanya ditentukan dari besar kecilnya hutang sebuah perusahaan tetapi juga ditentukan oleh faktor kinerja perusahaan. Sedangkan peran Capital Structure dengan proksi Debt to Equity Ratio sebagai mediasi Corporate Governance terhadap Firm Value dalam penelitian ini juga tidak terbukti, hal ini dikarenakan Debt to Equity Ratio ternyata tidak ada hubungan nilai perusahaan yang tercermin dalam potensi pertumbuhan perusahaan yang diukur melalui Tobin's q pada sub sektor property dan real estate.
Banyaknya faktor fundamental lain selain Capital Structure suatu perusahaan yang dapat mempengaruhi nilai sebuah perusahaan merupakan salah satu faktor penyebab tidak signifikannya peran mediasi Capital Structure perusahaan terhadap firm value, faktor lain seperti tingkat likuiditas ataupun kinerja keuangan perusahaan yang seringkali dinilai lebih relevan untuk dijadikan sebagai faktor pertimbangan dalam menilai sebuah perusahaan. Hasil penelitian ini sejalan dengan penelitian Mahendra (2011), yang menghasilkan pengaruh lavarage terhadap nilai perusahaan yang memiliki pengaruh tidak signifikan pada nilai perusahaan.

5. Financial Performance memediasi pengaruh Corporate Governance terhadap firm value

Dalam penelitian ini menemukan bahwa ROA justru berpengaruh negatif terhadap nilai perusahaan. Semakin besar hasil ROA maka kinerja keuangan perusahaan semakin baik, rasio yang meningkat menunjukkan bahwa kinerja manajemen meningkat dalam mengelola sumber dana pembiayaan operasional secara efektif untuk menghasilkan laba bersih. Hal tersebut seharusnya akan akan berdampak positif pada peluang pertumbuhan perusahaan dan keyakinan investor dalam penempatan investasinya.

Tetapi penelitian yang dilakukan pada perusahaan sub sektor property dan real estate ini menunjukkan hal sebaliknya yaitu ROA berpengaruh negatif terhadap Firm Value melalui tobin's $q$. Menurut peneliti hal ini menunjukkan adanya faktor lain yang turut mempengaruhi Firm Value seperti rasio-rasio profitabilitas yang lain serta faktor realisasi pertumbuhan perusahaan yang diukur dengan nilai pertumbuhan aktiva dan ekuitas. Penelitian ini sejalan dengan penelitian Suranta dan Pranata (2004)

Dalam hipotesis kelima ini menunjukkan bahwa pengaruh tidak langsung Corporate Governance terhadap Firm Value melalui Financial Performance berpengaruh. Hal ini disebabkan pengaruh langsung Corporate Governance terhadap variabel kinerja keuangan adalah signifikan hal ini ditunjukkan dengan adanya komite audit independen sebuah perusahaan akan lebih transparan dan akuntabel dalam meningkatkan kinerja keuangan mereka, karena dengan prinsip transparansi dan akuntabilitas akan dapat mengurangi risiko yang mungkin dilakukan oleh manajer atau 
direksi dengan keputusan yang menguntungkan sendiri. Pengaruh Financial Performance sebagai mediasi Corporate Governance terhadap Firm Value dalam penelitian ini juga terbukti. Hal ini dikarenakan Financial Performance yang dalam penelitian ini di proksi menggunakan ROA menjadi salah satu informasi penting di dalam menilai kondisi perusahaan baik jangka pendek maupun jangka panjang. Informasi ini berkaitan erat dengan potensi pertumbuhan perusahaan dan pada akhirnya akan mempengaruhi tingkat kepercayaan investor kepada permintaan saham.

\section{Keterbatasan}

Dalam penelitian ini secara umum berusaha menjawab perumusan dan tujuan penelitian, namun terdapat keterbatasan dalam penelitian ini yaitu:

1. Pada dasarnya indikator pembentuk Corportae Governance tidak hanya komite audit independen, akan tetapi masih banyak yang lain seperti kepemilikan manajerial, jumlah dewan komisaris, jumah dewan direksi dan lain-lain. Belum banyaknya preresearch Corporate Governance pada penelitian ini turut memberikan pengaruh pada perhitungan statistik. Pre-research pada variabel Corporate Governance dapat dilakukan melalui survey langsung pada perusahaan, penggunaan pre-research ini akan mendukung penelitian selanjutnya agar bisa menjelaskan secara detail pengaruh indikator pada variabel.

2. Jumlah sampel untuk penelitian ini berjumlah 15 perusahaan, kecilnya jumlah sampel tersebut dikarenakan perusahaan yang layak yang memiliki data lengkap terkait dengan variabel-variabel yang digunakan dalam penelitian hanya 15 perusahaaan pada sub sektor property dan real estate pada Bursa Efek Indonesia periode 2011-2014.

\section{KESIMPULAN DAN SARAN \\ Kesimpulan}

Beberapa kesimpulan penelitian dapat dikemukakan sebagai berikut:

1. Pengaruh Corporate Governance yang diwakili dengan indikator komite audit independen dalam penelitian ini dapat disimpulkan tidak signifikan terhadap struktur modal. Hal ini menunjukkan bahwa komite audit independen belum secara optimal dapat mempengaruhi keputusan penggunaan kewajiban untuk digunakan dalam penambahan modal. Alasan yang mendasari hasil uji penelitian ini adalah dengan adanya komite audit independen di suatu perusahaan yang menerapkan Corporate Governance diduga hanya sebagai formalitas belaka.

2. Dengan ditegakkannya praktik tata kelola yang baik seperti keterbukaan dan transparansi keuangan. Mereka secara otomatis akan membangun ikatan kepercayaan dengan pemangku kepentingan yaitu pemerintah, pelanggan, dan masyarakat. Beberapa pemangku kepentingan khususnya pelanggan pada gilirannya akan menginvestasikan dana mereka di bank-bank.

3. Para investor belum tentu memahami kapasitas dari anggota komite audit pada perusahaan, sehingga para investor tetap akan mempertimbangkan faktor lain yang lebih dominan seperti budaya organisasi dan Financial Performance perusahaan dalam mengambil keputusan investasi. Penelitian yang dilakukan oleh Ratih (2011) juga menghasilkan laporan yang sama, bahwa GCG tidak signifikan berpengaruh terhadap nilai perusahaan dengan implementasi penelitian pada perusahaan manufaktur yang mendapatkan peringkat The Indonesia Most Trusted Companies.

4. Financial Performance menjadi salah satu informasi penting di dalam menilai kondisi perusahaan baik jangka pendek maupun jangka panjang. Informasi ini berkaitan erat dengan tingkat kepercayaan investor kepada suatu saham. Kinerja keuangan yang baik akan menghasilkan keuntungan yang tinggi, keuntungan yang tinggi akan memberikan indikasi prospek perusahaan yang baik sehingga memicu investor untuk ikut meningkatkan permintaan saham.

\section{Saran}

Saran dalam penelitian ini diberikan berdasarkan temuan penelitian dan adanya keterbatasan penelitian, maka peneliti memberikan beberapa saran yaitu:

1. Manajemen disarankan untuk meningkatkan perbaikan pada sistem penggunaan Corporate Governance, karena perbaikan pada kualitas penerapan Corporate Governance akan berdampak 
pada kredibilitas perusahaan. Corporate govenance merupakan suatu proses dan bukan hanya merupakan tanggung jawab dewan komisaris atau pemegang saham tetapi tanggung jawab semua board of director, komite audit independen dan stakeholders lainnya. Semua pihak yang terkait, terutama yang memiliki fungsi struktural, untuk melakukan kontrol berfungsinya semua bagian akan meningkatkan laba, pertumbuhan penjualan dan menurunkan biaya-biaya.

2. Dalam penelitian ini Capital Structure tidak terbukti memediasi Corporate Governance terhadap firm value. Sehubungan dengan hal itu, maka dari itu penelitian ini perlu ditindaklanjuti dengan penelitian lain untuk menemukan bukti empiris secara langsung atau tidak langsung mengenai faktor-faktor apa saja yang mempengaruhi Firm Value perusahaan.

3. Pengembangan proksi yang lebih mewakili variabel-variabel penelitian diharapkan dapat menghasilkan pengujian yang lebih baik lagi. Hal lain juga perlu diperhatikan adalah penggunaan variabel independen lain dan variabel mediasi lain selain variabel-variabel yang sudah diuji dalam penelitian ini.

\section{Implikasi Penelitian}

1. Bagi manajemen perusahaan, manajemen harus lebih memperhatikan arti pentingnya Corporate Governance khususnya indikator komite audit independen. Komite audit independen secara kolektif berfungsi untuk membantu komisaris dan dewan pengawas dalam melaksanakan tugas pengawasan atas kebijakan yang ditetapkan manajemen perusahaan. Komite audit independen dapat mengevaluasi kebijakan-kebijakan perusahaan yang telah ditetapkan, dengan penerapan kebijakan yang benar maka profitabilitas suatu perusahaan dan terwujud dengan baik.

2. Bagi Investor, Investor perlu mempertimbangkan Financial Performance untuk melakukan penilaian mengenai kemampuan perusahaan dalam menjamin pengembalian dan pemenuhan kewajiban perusahaan dengan baik. Dengan memperhatikan hal tersebut tujuan investor untuk memperoleh keuntungan sebesar-besarnya dengan tingkat risiko kecil dapat tercapai.

\section{Daftar Pustaka}

Amidu, M. 2007. Determinants of Capital Structure in Ghana: an empirical approach. Baltic Journal of Management, 2 (1), 6779.

Amri, Chairul \& Dr. Untara. 2011. Analisis Pengaruh Kinerja Keuangan, Good Corporate Governance dan Corporate Social Responbility Terhadap Nilai Perusahaan. Working Paper. 2011, 12-17

Arsiraphongphisit dan Ariff. 2004. Optimal Capital Structure and Firm Value Australian Evidence :1991 - 2003. EFM Classification. Corporate Finance 140

Baron, R. M \& Kenny, D.AA. 1986. The Moderator-Mediator Variable Distinction in Social Psychological Research: Conceptual, Strategic, and Statistical Considerations. Journal of Personality and Social Psychology. 51 (6): 1173-1182

Ben-Naceur, Samy dan Mohamed Goaied. 2002. The Relationship between Dividend Policy, Financial Structure, Profitability and Firm Value. Applied Financial Economics, 12(12), 843-49.

Boediono, Gideon. 2005. Studi Pengaruh Mekanisme Corporate Governance dan Dampak Menejemen Laba dengan Menggunakan Analisis Jalur. Simposium Nasional Akuntansi (SNA) VIII Solo.

Bradley, M., G. A. Jarrell., \& E. H. Kim. 1984. On the existence of an optimal capital structure: theory and evidence. The Journal of Finance, 39, 857-878.

Brealey, R. A., Myers, S. C. \& Allen, F. 2006. Corporate Finance, 8th edition, McGrawHill Irwin.

Brigham, E. F. \& M. C. Ehrhardt. 2005. Financial management: theory and practice. South-Western: Cengage Learning.

Byun, D. H., J. Kim., \& J. Y. Shin. 2007. Compensation structures and firm value. Asia-Pasific Management Accounting Journal, 2, 35-51.

Chen, C. R., W. Guo, dan V. Mande. 2006. Corporate value, managerial stockholdings and investments of japanese firms. International Financial Management and Accounting, 17, 29-51. 
Cho, H. J. \& V. Pucik. 2005. Relationship between innovativeness, quality, growth, profitability, and market value. Strategic Management Journal, 26, 555-575.

Coleman, Anthony. 2007. Corporate Governance And Firm Performance in Africa: A Dynamic Panel Data Analysis. Journal of finance, vol. 57, no. 6, december, pp. 2741-2771

Cremers, K.J.M. \& V.B. Nair. 2005 Governance Mechanisms and Equity Prices. Journal of Finance, 25:6, 2859-93

Florackis. 2008. Agency Cost and Corporate Governance Mecanism : evidence for UK. Corporate Governance . 14,34-50.

Garay \& González. 2008. Corporate Governance and Firm Value: The Case of Venezuela. Corporate Governance. Journal of Management. vol. 16 No 3 pp.194-209.

Gitman J. Lawrence and Chad J. Zutter. 2012. Principle of Managerial Finance, 13th edition. England : Pearson.

Hadiprajitno. 2012. Pengaruh Good Corporate Governance pada Hubungan Corporate Social Responsibility dan Nilai Perusahaan manufaktur yang Terdaftar di BEI. Jurnal Akuntansi \& Auditing Vol. 9 (1) : 88. Universitas Diponegoro, Semarang

Hunger, J. David \& Wheelen Thomas L. 2004. Strategic Management and Bussines Policy. Ninth edition, New York: Prentice Hall.

Jensen, Michael C. \& William H. Meckling 1978. Theory of the Firm: Managerial Behavior, Agency Costs and Ownership Structure: Journal of Financial Economics, October, 1976, V. 3, No. 4, pp. 305-360.

Kautsar, Ahmad. 2015. Analisis Pengaruh Good Coorporate Governance Terhadap Kinerja Perusahaan yang Dimediasi Struktur Modal. Jurnal Ekonomi Volume 15, No. 1, Januari - Juni 2015, Halaman 59-75

Kim, W. S. \& E. H. Sorensen. 1986. Evidence on the impact of the agency costs of debt on corporate debt policy. The Journal of Financial and Quantitative Analysis, 21, 131-144.

Klapper, L. \& Love. 2002. Corporate Governance, Investor Protection and Performance in Emerging Markets. World Bank Working Paper.
Mahendra Dj, Alfredo. 2011. Pengaruh Kinerja Keuangan Terhadap Nilai Perusahaan (Kebijakan Deviden sebagai Variabel Moderating) Pada Perusahaan Manufaktur di Bursa Efek Indonesia. (Thesis). Program Pascasarjana Universitas Udayana Denpasar.

Modigliani, F. \& M. H. Miller. 1958. The cost of capital, corporation finance and the theory of investment. The American Economic Review, 48 (3), 261-297.

Myers, S. C. \& N. S. Majluf. 1984. Corporate financing and investment decisions when firms have information that investor do not have. Journal of Financial Economics, 13, 187-221.

Ratih, Sukimah. 2011. Pengaruh Good Corporate Governance Terhadap Nilai Perusahaan dengan Kinerja Keuangan sebagai Variabel Intervening. Jurnal Kewirausahaan Volume 5 Nomor 2, Desember 2011. ISSN. 1978-4724

Riduwan dan Kuncoro, E. A. 2010. Cara menggunakan dan Memakai Path Analysis. Bandung: Alfabetha.

Ruan, Wenjuan., Tian Gary., \& Ma, Shiguan. 2011. Managerial Ownership, Capital Str ucture and Firm Value: E vidence from China's Civi lian-run Firms. Australasian Accounting Business and Finance Journal, Volume 5 nomor 3, p. 73 - 92.

Setiabudi, Andi \& Agustia, D. 2012. Fundamental Factor of Firm Due to Firm Value. Journal of Basic and Aplied Scientific Research, 2, 12, 12651-12659.

Sundjajda, Ridwan S \& Barlian, Inge. 2003. Manajemen Keuangan Satu. Literara: Lintas Media Jakarta

Suranta, Eddy \& Pratana Puspita. 2004. Incoming Smoothing, Tobins Q, Agency problem dan kinerja perusahaan. Simposium Nasional Akuntansi VII. Bali, 2-3 Desember

Sutrisno. 2003. Manajemen Keuangan: Teori, Konsep, dan Aplikasi. Edisi Pertama, Cetakan Kedua. Ekonisia. Yogtakarta.

Tahir, I.Z., dan Razali, A.R. 2011. The Relationship Between Enterprise Risk Management (ERM) And Firm Value: Evidence From Malaysian Public Listed Companies. International Journal of Economics, 32-41.

Wardani, D. Kusuma \& Hermuningsih. 2011. Pengaruh struktur kepemilikan terhadap nilai perusahaan dengan kinerja 
keuangan dan kebijakan hutang sebagai variabel intervening. Jurnal Siasat Bisnis.

Januari 2011. Vol. 15, 1, 27-36.
Zarkasyi, Moh. Wahyudin. 2008. Good Corporate Governance: Pada Badan Usaha Manufaktur, Perbankan, dan Jasa Keuangan Lainnya. Jakarta: Alfabeta. 